\title{
Preventive effects of glycyrrhizin on estrogen-related endometrial carcinogenesis in mice
}

\author{
KENJI NIWA ${ }^{1}$, ZENGLIN LIAN $^{1}$, KYOKO ONOGI $^{1}$, WU YUN $^{1}$, LIULIN TANG ${ }^{1}$, \\ HIDEKI MORI $^{2}$ and TERUHIKO TAMAYA ${ }^{1}$ \\ Departments of ${ }^{1}$ Obstetrics and Gynecology and ${ }^{2}$ Tumor Pathology, Gifu University \\ School of Medicine, 1-1 Yanagido, Gifu-city, Gifu 501-1194, Japan
}

Received August 31, 2006; Accepted November 3, 2006

\begin{abstract}
We have previously reported on the inhibitory effect of Glycyrrhizae radix (Gl radix) on mouse endometrial carcinogenesis. The present study was performed to clarify the effects of $G l$ radix and glycyrrhizin (GL), the main part of $G l$ radix, on estradiol $\left(\mathrm{E}_{2}\right)$-related endometrial carcinogenesis. Both $G l$ radix and GL exerted a significant decrease in the COX-2, IL- $1 \alpha$ and TNF- $\alpha$ mRNA expressions. GL generated a significant decrease in the incidence of endometrial adenocarcinoma. Accordingly, the preventive effects of Gl radix may be attributable to GL, thus being related with the suppression of COX-2, IL- $1 \alpha$ and TNF- $\alpha$. Gl radix and GL could therefore be a promising formula for the chemoprevention of human endometrial cancer.
\end{abstract}

\section{Introduction}

Glycyrrhizin (GL), a major constituent of Glycyrrhizae radix ( $G$ l radix) which is $\sim 10 \%$ of the dry weight of $G$ radix extract, is the calcium and potassium salt of glycyrrhizinic acid. GL glycoside loses its sweet taste and upon hydrolysis is then converted to aglycone glycyrrhetinic acid plus two molecules of glucuronic acid. GL has an anti-estrogenic as well as an estrogenic effect (1). There is some evidence that GL has a protective effect on the skin $(2,3)$ or liver carcinogenesis $(4,5)$.

It is known that $G l$ radix is widely used as a Kampo medicine in Asian countries and $75 \%$ of traditional Japanese and Chinese medicines contain this agent. We have previously

Correspondence to: Dr Kenji Niwa, Departments of Obstetrics and Gynecology, Gifu University School of Medicine, 1-1 Yanagido, Gifu-city, Gifu 501-1194, Japan

E-mail: kniwa@gifu-u.ac.jp

Abbreviations: GL, glycyrrhizin; $\mathrm{E}_{2}$, estradiol-17ß; COX, cyclooxygenase, IL-1 $\alpha$, interleukin- $1 \alpha$; TNF, tumor necrosis factor

Key words: glycyrrhizin, Glycyrrhizae radix, chemoprevention, endometrial carcinogenesis, COX-2 reported that $G l$ radix has a preventive effect on endometrial carcinogenesis in mice, and this effect is related to the inhibition of the expression of estrogen-stimulated genes $c$-fos/jun mRNA and proteins (6). We also proved that the herbal complex containing Gl radix suppresses cell proliferation in a chemo-endocrine resistant cancer cell line (7). In general, the anti-estrogenic effects are considered to have a protective effect against the occurrence of estrogendependent cancers. Such effects are confirmed in animal models of uterine endometrial cancer (8).

Cyclooxygenase (COX), an enzyme that activates the production of prostaglandins from arachidonic acid, has two isoforms. COX-2 has attracted considerable attention in connextion with carcinogenesis in organs such as the large bowel, mammary glands and breast carcinogenesis (9-11). There is evidence that the COX activity is related to the promotion and progression in the tumorigenesis of the prostatic gland, stomach and lung (12-14). It remains unclear whether COX-2 is involved in $\mathrm{E}_{2}$ related mouse endometrial carcinogenesis, although a high expression level of COX-2 has been confirmed in human endometrial carcinomas (15). In this study, we examined the possible association of the preventive effects of GL on $\mathrm{E}_{2}$-induced mouse endometrial carcinogenesis with COX-2 activity.

We have reported that the expression of internal cytokines, interleukin (IL)- $1 \alpha$ and tumor necrosis factor (TNF)- $\alpha$, increase after $E_{2}$ treatment (16). Such an increase of the internal cytokines is suggested to contribute to both tumor promotion and progression (17-19). Such circumstances prompted us to clarify the effects of GL on endometrial carcinogenesis in mice. Therefore, the expression of IL- $1 \alpha$ and TNF- $\alpha$ were examined to indentify any further mechanism(s) of the effects of Gl radix and GL in the uteri of ovarectomized mice.

\section{Materials and methods}

Animals and chemicals. Female ICR mice were purchased from Japan SLC Co. (Shizuoka, Japan). As a basal diet, Oriental MF (Oriental Yeast Co., Tokyo, Japan) was used. Both the basal diet and filtered tap water were available ad libitum throughout the experiment. $\mathrm{E}_{2}$ and GL were purchased from Sigma Chemical Co. (St. Louis, MO), and 
Table I. Sequences of primers.

Primers Nucleotide sequences

Citation

COX-1 sense

COX-1 antisense

COX-2 sense

COX-2 antisense

IL-l $\alpha$ sense

IL-l $\alpha$ antisense

TNF- $\alpha$ sense

TNF- $\alpha$ antisense

GAPDH sense

GAPDH antisense
5'-TGCATGTGGCTGTGGATGTCATCAA-3'

5'-CACTAAGACAGACCCGTCATCTCCA-3'

5'-ACTCACTCAGTTTGTTGAGTCATTC-3'

5'-TTTGATTAGTACTGTAGGGTTAATG-3'

5'-GATGGCCAAAGTTCCTGACTTG-3'

5'-GCCTGACGAGCTTCATCA-3'

5'-AGGCAGGTTCTGTCCCTTTCA-3'

5'-TCCACTTGGTGGTTTGCTACG-3'

5'-CAAGGTCATCCCAGAGCTGAA-3'

5'-GCAATGCCAGCCCCGGCATCG-3'
21

21
Gl radix (powder of the crude extract) was purchased from Tsumura Co. (Tokyo, Japan), respectively.

Experimental protocol for short-term experiment. Female (12 weeks old) ICR mice were ovariectomized at laparotomy under general anesthesia with diethylether. Two weeks later, the ovariectomized mice were divided into 6 experimental groups (6 mice in each). Group 1 was given daily $0.625 \%$ Gl radix and 5 ppm $\mathrm{E}_{2}$-containing diet; Group 2 was fed with $0.0625 \%$ of GL and 5 ppm $\mathrm{E}_{2}$; Group 3 was exposed to $5 \mathrm{ppm}$ $\mathrm{E}_{2}$-containing diet alone; Group 4 was given daily $0.625 \%$ Gl radix alone; Group 5 was fed $0.0625 \%$ GL alone. Group 6 was given the basal diet only as a control. The dose of $0.625 \%$ Gl radix in the diet has been proven to be sufficient to inhibit the estrogenic action of 5 ppm $\mathrm{E}_{2}(1,2)$, and the concentration, at the GL diet was calculated to be $10 \%$ of the $0.625 \%$ Gl radix. After two weeks feeding with the diet containing the above agents, the mice uteri were resected and cut in half longitudinally. One half was quickly frozen in the liquid nitrogen for the following experiments, while the other specimen was submitted to a pathological examination.

Reverse transcription-polymerase chain reaction ( $R T-P C R)$. Total-RNA was isolated from frozen tissue specimens by the guanidium thiocyanate-phenol-chloroform extraction method (20). Total RNA $(3 \mu \mathrm{g})$ was reverse transcribed with Moloney murine leukemia virus reverse transcriptase (MMLV-RTase, 200 units, Gibco BRL, Gaithersburg, MO) in $20 \mu \mathrm{M}$ Tris- $\mathrm{HCl}$ buffer (pH 8.4) with $50 \mu \mathrm{M} \mathrm{KCl}, 2.5 \mu \mathrm{M} \mathrm{MgCl}_{2}, 0.1 \mu \mathrm{g} / \mathrm{ml}$ bovine serum albumin, $10 \mu \mathrm{M}$ dithiothreitol, and $0.5 \mu \mathrm{M}$ deoxynucleotides to generate cDNAs, using random hexamers (50 $\mathrm{ng}, \mathrm{Gibco} \mathrm{BRL}$ ) at $37^{\circ} \mathrm{C}$ for $60 \mathrm{~min}$. $\mathrm{RT}$ reaction was heated at $94^{\circ} \mathrm{C}$ for $5 \mathrm{~min}$ to inactivate MMLV-RTase. For COX-1 (450 bp), extension of 35 cycles was performed consisting of $1 \mathrm{~min}$ at $94^{\circ} \mathrm{C}$ for denaturation, $1 \mathrm{~min}$ at $57^{\circ} \mathrm{C}$ for annealing, and for COX-2 (583 bp) of PCR consisting of $1 \mathrm{~min}$ at $72^{\circ} \mathrm{C} 15 \mathrm{sec}$ at $94^{\circ} \mathrm{C}$ for denaturation, $1 \mathrm{~min}$ at $55^{\circ} \mathrm{C}$ for annealing, and $1 \mathrm{~min}$ at $72^{\circ} \mathrm{C}$ for extension. PCR (30 or 25 cycles), consisting of $1 \mathrm{~min}$ at $94^{\circ} \mathrm{C}$ for denaturation, $1 \mathrm{~min}$ at $55^{\circ} \mathrm{C}$ for annealing, and $1.5 \mathrm{~min}$ at $72^{\circ} \mathrm{C}$ for extension, for TNF- $\alpha$ (369 bp) and IL-1 $\alpha$ (401 bp). They were carried out in reverse transcribed cDNAs with $0.1 \mathrm{mM}$ specific primers described below, using the IWAKI thermal sequencer TSR-300 (IWAKI Glass, Tokyo) with Vent DNA polymerase (New England Biolabs, Beverley, MA) in $20 \mu \mathrm{M}$ Tris- $\mathrm{HCl}$ buffer (pH 8.8) with $10 \mu \mathrm{M} \mathrm{KCl}, 10 \mu \mathrm{M}\left(\mathrm{NH}_{4}\right)_{2} \mathrm{SO}_{4}, 2 \mu \mathrm{M} \mathrm{MgSO}_{4}$, $0.1 \%$ Triton $\mathrm{X}-100$, and $0.15 \mu \mathrm{M}$ deoxynucleotide phosphates. PCR (20 cycles) for glyceraldehyde-3-phosphate dehydrogenase (GAPDH, a house-keeping gene) mRNA (252 bp) as an internal standard was performed at the same time.

The following oligodeoxynucleotides were synthesized as specific primers in PCR according to the published information [cDNA for COX-1/2 (21), IL-1 $\alpha$ (22) TNF- $\alpha$ (23) and GAPDH (24)] as shown in Table I.

Semi-quantitative analysis of the COX-1, COX-2, IL-1 $\alpha$ and $T N F-\alpha$ mRNA expressions by PCR products. PCR products were applied on $1.5 \%$ agarose gel electrophoresis at 50-100 V. The quantification of the products was carried out using Bio image (Millipore Corp.). The intensity of specific bands was standardized with that of GAPDH mRNA.

Immunohistochemical expression of COX-1/2, IL-1 $\alpha$ and $T N F-\alpha$ protein. After being fixed in $10 \%$ formalin, half the uterine corpus was processed by conventional staining methods. Briefly, the avidin-biotin-peroxidase complex was applied on the sections using a Vestain kit (Vector, Burlingame, CA). The primary antibodies used were against the proteins of COX-1 (1:250, anti-mouse monoclonal, Cayman Chemial, Ann Arbor, MI) and COX-2 (1:200, anti-mouse monoclonal, Alexis Biochem., Carlsbad, CA). IL-1 $\alpha$ (1:200, anti-rabbit polyclonal, Santa Cruz Biotech Inc., Santa Cruz, CA) and TNF- $\alpha$ (1:100, anti-goat polyclonal, Santa Cruz Biotech Inc.).

Immunohistochemical COX-1/2 expressions in glandular and stromal cells were scored separately according to the criteria of Krajewska et al (25). The scoring methods were modified by Fujiwaki et al (26). Namely, the percentage of COX-1 and -2 immunostaining in the glandular and stromal cells were graded as follows: 0 , no staining; $1,1-25 \% ; 2$, $26-50 \% ; 3,51-75 \%$; and $4,76-100 \%$. The intensity of immunostaining was rated as: 0 , none; 1 , weak; 2 , moderate; 3 , intense. As a result, the immunohistochemical COX scores 

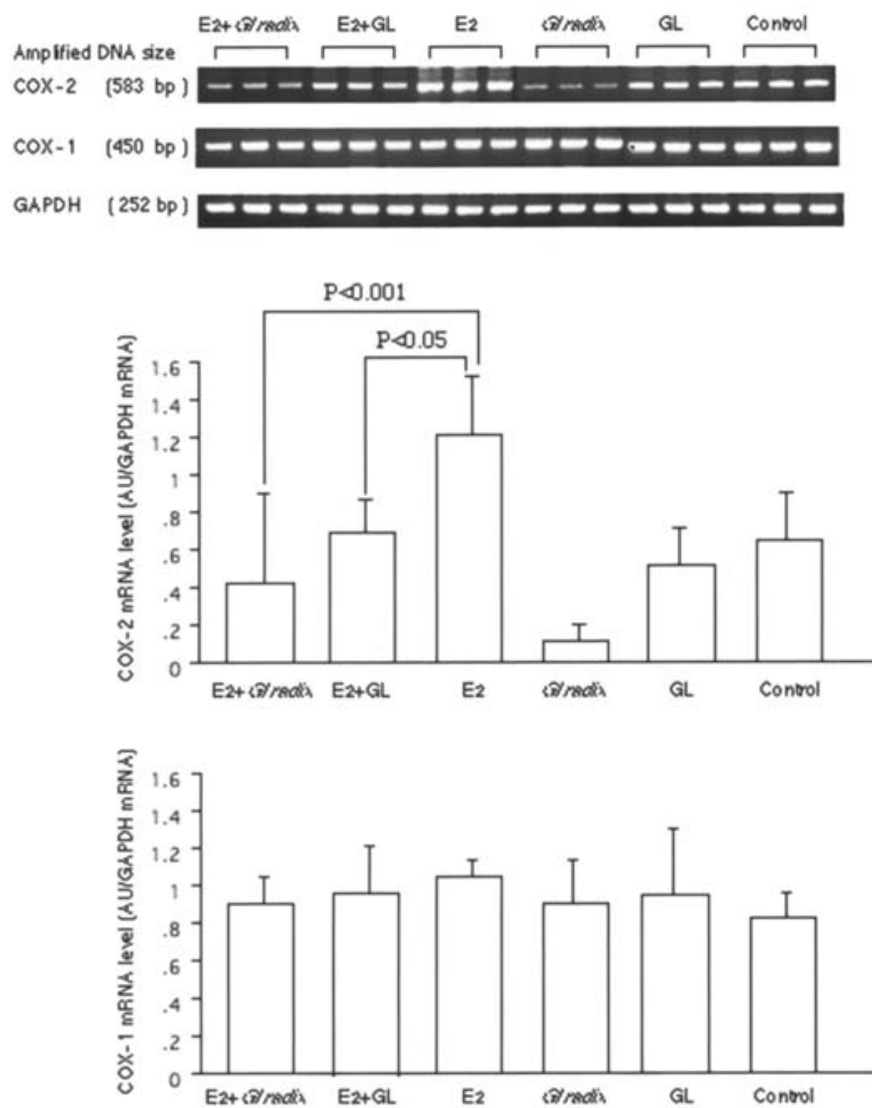

Figure 1. Expression of COX-1 and COX-2 mRNA in the uterus of the ovariectomized mice, treated continuously for two weeks with $\mathrm{E}_{2}$ plus Gl radix or $\mathrm{GL}, \mathrm{E}_{2}$, and $\mathrm{Gl}$ radix or GL alone. Gl radix, Glycyrrhizae radix; GL, Glycyrrhizin. The COX-2 mRNA in the group treated with $\mathrm{E}_{2}$ plus Gl radix or GL was significantly lower than that in the group treated with $\mathrm{E}_{2}$ alone $(\mathrm{P}<0.05)$.

ranged from 0 to 12 (26). The immunohistochemical findings were analyzed by two independent investigators counting $>200$ cells and discordant results were reviewed jointly.

The staining intensity for IL- $1 \alpha$ and TNF- $\alpha$ protein was assigned as: (+), positive; (+/-), minimally or randomly positive; (-), negative (27).

Experimental protocol for long-term effects of GL. The protocol was: A total number of 125 female ICR mice, 12 weeks of age, underwent a laparotomy under general anesthesia with diethylether. MNU solution (total volume: $0.1 \mathrm{ml}$ ) at a dose of $1 \mathrm{mg} / 100 \mathrm{~g}$ body weight was injected into the left uterine tube and normal saline into the right. One week after MNU exposure, the animals were divided into 6 groups. Group 1 (35 mice) was given the diet with $0.0625 \% \mathrm{GL}$ and $5 \mathrm{ppm} \mathrm{E}_{2}$. Group 2 (30 mice) was given the $5 \mathrm{ppm} \mathrm{E}_{2}-$ containing diet alone. Group 3 (30 mice) was given the diet with $0.0625 \%$ GL. Group 4 (30 mice) was treated with the basal diet only as a control. At 30 weeks after the MNU exposure, all animals were sacrificed and autopsied. All major organs, especially the reproductive organs, were grossly inspected.

Any lesions in the uterus, ovaries, vagina suspected of being neoplastic and hyperplastic were cut in half. The tissue specimens were submitted to a histopathological examination. The tissue specimens were then cut in $3-\mu \mathrm{m}$ slices and then were stained with hematoxylin and eosin.
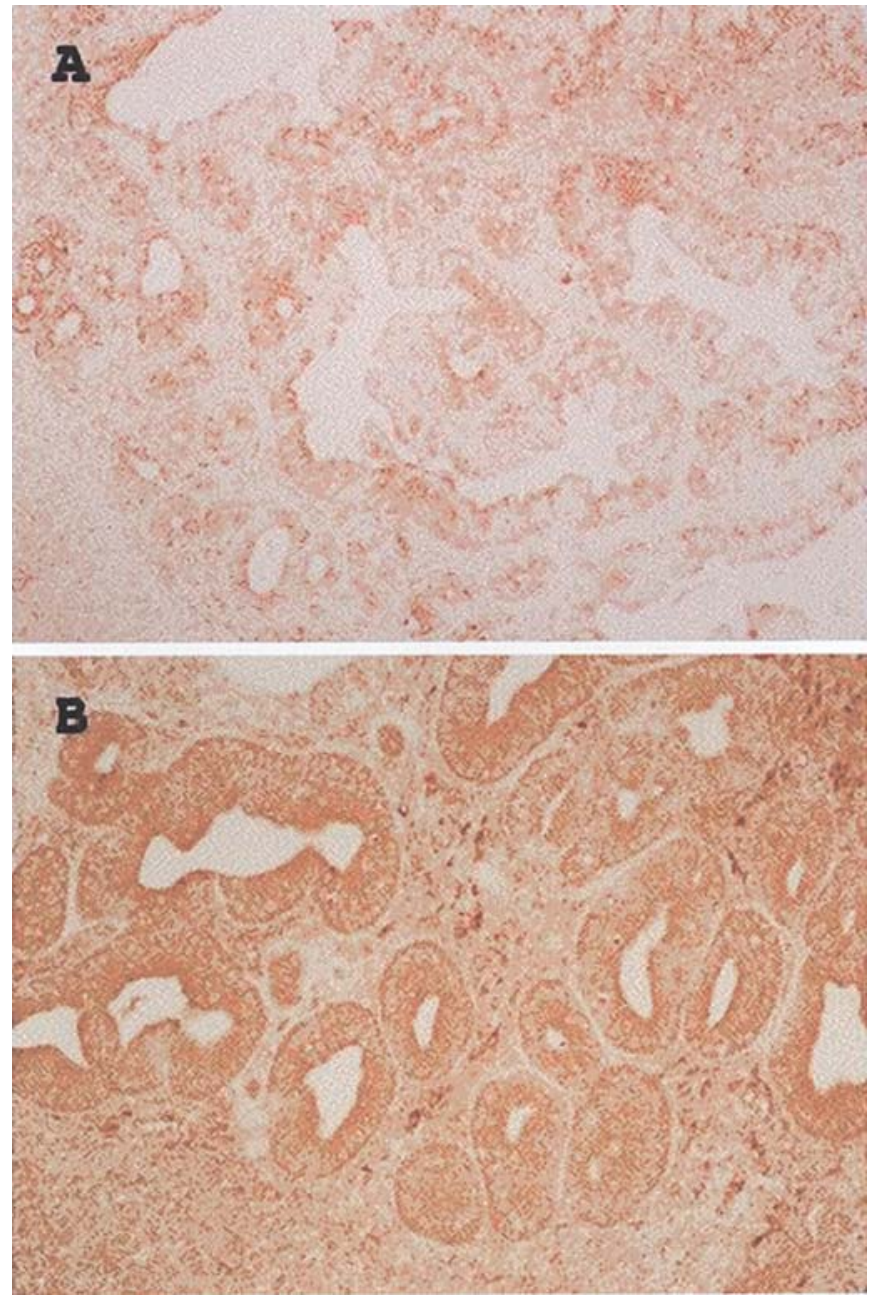

Figure 2. The expression of COX-2 in the uteri of ovariectomized mice treated orally for 2 weeks with $\mathrm{E}_{2}$ and $G$ l radix to resection of the uteri (A) (sABC stain, $\mathrm{x} 350$ ), and with $\mathrm{E}_{2}$ alone (B) (sABC stain, $\mathrm{x} 350$ ). The expression with $\mathrm{E}_{2}$ and $G$ radix was also prominent in the glandular cells, and it was weaker than that in the case of $\mathrm{E}_{2}$ alone.

Histology of the uterine lesion. According to the WHO criteria (28), uterine endometrial lesions were divided into 4 types of lesions: a) endometrial hyperplasia, simple; b) endometrial hyperplasia, complex; c) atypical endometrial hyperplasia; d) adenocarcinoma.

Statistical analysis. A statistical analysis was done according to either the $\chi^{2}$ test or Student's t-test.

\section{Results}

Short-term experiment. The expression of COX-1/2 mRNAs is shown in Fig. 1. The level of COX-1 mRNA expression did not change after any treatment, however, the COX-2 mRNA expression which had been overexpressed in the $\mathrm{E}_{2}$ group significantly decreased after either the Gl radix or GL treatment $(\mathrm{P}<0.001, \mathrm{P}<0.05$, respectively). The results of the protein expression are summarized in Table II. The immunohistochemical score significantly decreased after treatment with either $G l$ radix or GL $(\mathrm{P}<0.05)$. The representative expression pattern of COX-2 protein is indicated in Fig. 2A and B. The 
Table II. Immunohistochemical expression of COX-1/2 in the ovarectomized mouse uteri.

\begin{tabular}{|c|c|c|c|c|c|}
\hline \multirow[b]{2}{*}{ Group } & \multirow[b]{2}{*}{ Treatment } & \multicolumn{2}{|c|}{ COX-1 } & \multicolumn{2}{|c|}{$\mathrm{COX}-2$} \\
\hline & & Glandular cells & Stromal cell & Glandular cells & Stromal cells \\
\hline 1 & $\mathrm{E}_{2}+\mathrm{Gl}$ radix & $2.5 \pm 0.8^{\mathrm{a}}$ & $2.0 \pm 0.7$ & $3.0 \pm 1.7^{\mathrm{b}}$ & $4.6 \pm 1.2$ \\
\hline 2 & $\mathrm{E}_{2}+\mathrm{GL}$ & $3.0 \pm 0.4$ & $1.8 \pm 0.5$ & $3.7 \pm 1.5^{\mathrm{b}}$ & $5.0 \pm 1.0$ \\
\hline 3 & $\mathrm{E}_{2}$ alone & $3.5 \pm 0.6$ & $2.0 \pm 0.2$ & $7.6 \pm 2.1$ & $6.0 \pm 2.0$ \\
\hline 4 & Gl radix alone & $2.1 \pm 0.7$ & $1.1 \pm 0.3$ & $4.6 \pm 1.2$ & $0.8 \pm 0.2$ \\
\hline 5 & GL alone & $1.7 \pm 0.2$ & $1.0 \pm 0.1$ & $4.3 \pm 1.5$ & $1.3 \pm 0.6$ \\
\hline 6 & Control & $1.5 \pm 0.2$ & $1.2 \pm 0.2$ & $5.0 \pm 1.7$ & $3.3 \pm 1.5$ \\
\hline
\end{tabular}

${ }^{\mathrm{a}}$ Mean $\pm \mathrm{SD}$. ${ }^{\mathrm{b}}$ Significantly different from $\mathrm{E}_{2}$ group $(\mathrm{P}<0.05)$.
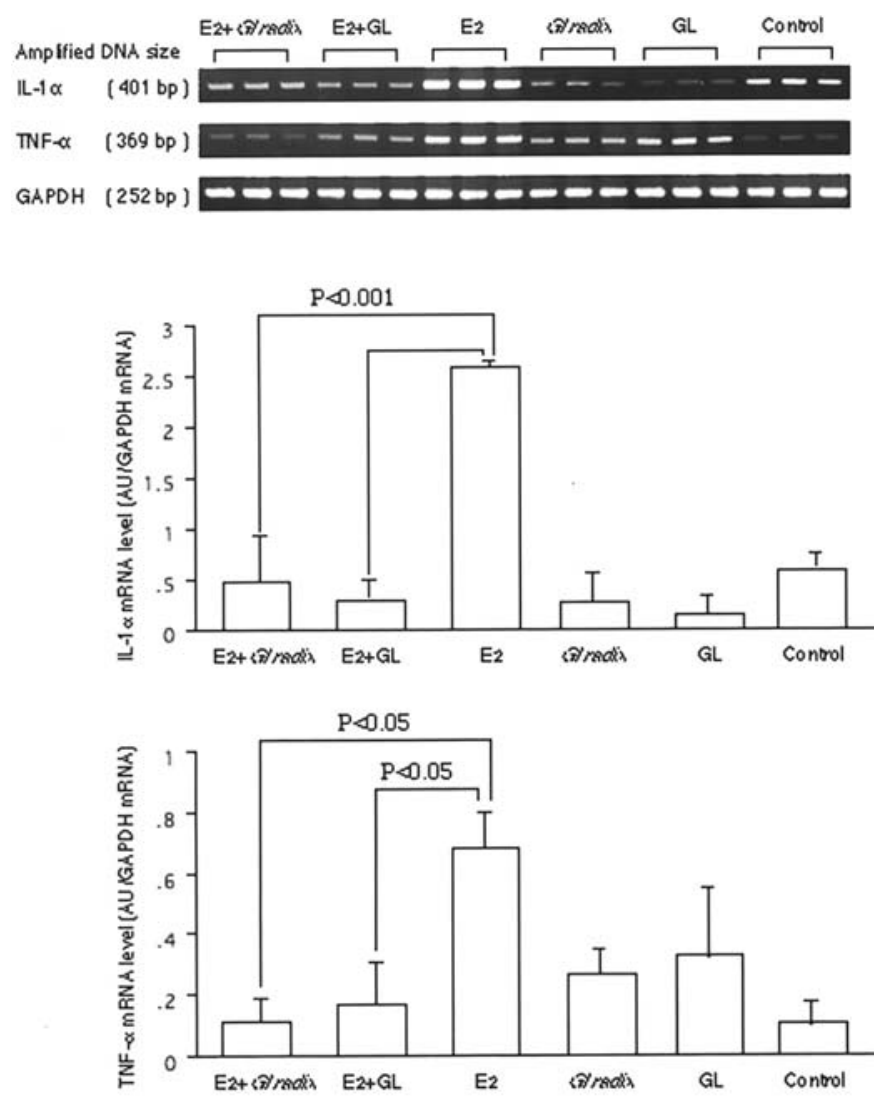

Figure 3. Expression of IL-1 $\alpha$ and TNF- $\alpha$ mRNA in the uterus of ovarectomized mice, treated continuously for two weeks with $\mathrm{E}_{2}$ plus Gl radix or GL, $\mathrm{E}_{2}$, and or GL alone. Gl radix, Glycyrrhizae radix; GL, Glycyrrhizin.

protein expression decreased after the $\mathrm{E}_{2}$ plus Gl radix treatment (Fig. 2A) in comparison to that of the $\mathrm{E}_{2}$ group (Fig. 2B).

The expression of IL- $1 \alpha$ and TNF- $\alpha$ mRNAs is shown in Fig. 3. Gl radix or GL exposure significantly decreased the level of IL-1 $\alpha$ mRNA induced by the $\mathrm{E}_{2}$ treatment $(\mathrm{P}<0.001)$. Gl radix or GL also decreased the expression of TNF- $\alpha$ mRNA generated by $\mathrm{E}_{2}$ treatment $(\mathrm{P}<0.05)$. The results of the immunohistochemical analysis are summarized in Table III.

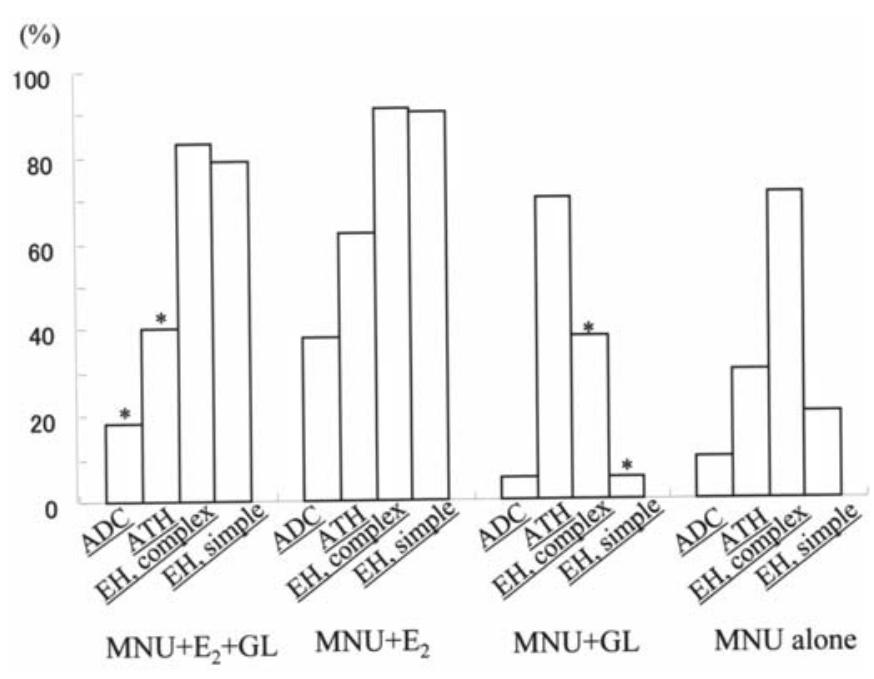

Figure 4. The incidence of neoplastic and preneoplastic endometrial lesions in each group. ${ }^{*} \mathrm{P}<0.05$ compared with the control group.

The protein expressions of IL- $1 \alpha$ and TNF- $\alpha$ demonstrated a similar pattern to the mRNAs in the same groups.

Long-term experiment for GL. The mean body weight and weight of the uterine corpora are summarized in Table IV. The mean wet weights of the uterine corpus in the groups treated with either $G l$ radix or GL were significantly less than in the group not treated by either Gl radix or GL. The incidence of neoplastic and preneoplastic endometrial lesions is summarized in Fig. 4. The incidence of endometrial adenocarcinoma and atypical endometrial hyperplasia in the GL plus $E_{2}$-treated group was significantly lower than that of the $\mathrm{E}_{2}$-treated group.

\section{Discussion}

We previously demonstrated that $G l$ radix has an inhibitory effect on $\mathrm{E}_{2}$-related endometrial carcinogenesis in mice (6). In the present study, the exposure to GL decreased the uterine weight in the long-term experiment, thus suggesting that GL has some anti-estrogenic effects at the dose used in this experiment. In the long-term experiment, the incidences of 
Table III. Immunohistochemical expression of IL-1 $\alpha$ and TNF- $\alpha$ in the ovarectomized mouse uteri.

\begin{tabular}{|c|c|c|c|c|c|}
\hline \multirow[b]{2}{*}{ Group } & \multirow[b]{2}{*}{ Treatment } & \multicolumn{2}{|c|}{ IL-l $\alpha$} & \multicolumn{2}{|c|}{ TNF- $\alpha$} \\
\hline & & Glandular cells & Stromal cells & Glandular cells & Stromal cells \\
\hline 1 & $\mathrm{E}_{2}+\mathrm{Gl}$ radix & + & \pm & + & \pm \\
\hline 2 & $\mathrm{E}_{2}+\mathrm{GL}$ & + & \pm & \pm & \pm \\
\hline 3 & $\mathrm{E}_{2}$ alone & ++ & + & ++ & + \\
\hline 4 & Gl radix alone & \pm & \pm & \pm & \pm \\
\hline 5 & GL alone & \pm & \pm & \pm & \pm \\
\hline 6 & Control & \pm & \pm & \pm & \pm \\
\hline
\end{tabular}

$(++)$, strongly positive; $(+)$, positive; $( \pm)$, minimally or randomly positive.

Table IV. Mean body weight and mean left uterine corpora in each group.

\begin{tabular}{|c|c|c|c|c|c|}
\hline Group & Treatment & $\begin{array}{l}\text { Initial number } \\
\text { of animals }\end{array}$ & \multicolumn{2}{|c|}{$\begin{array}{l}\text { Effective number of body weight }(\mathrm{g}) \\
\text { animals }\end{array}$} & $\begin{array}{l}\text { Wet weight of } \\
\text { uterine corpora }(\mathrm{g})\end{array}$ \\
\hline 1 & $\mathrm{MNU}+\mathrm{E}_{2}+\mathrm{GL}$ & 35 & 32 & $44.3 \pm 6.2^{\mathrm{a}}$ & $0.21 \pm 0.19$ \\
\hline 2 & $\mathrm{MNU}+\mathrm{E}_{2}$ alone & 30 & 25 & $43.1 \pm 3.0$ & $0.65 \pm 0.20^{\mathrm{b}}$ \\
\hline 3 & MNU + GL alone & 30 & 27 & $36.9 \pm 4.1$ & $0.17 \pm 0.10$ \\
\hline 4 & MNU alone & 30 & 27 & $48.0 \pm 6.0$ & $0.46 \pm 0.31^{\mathrm{b}}$ \\
\hline
\end{tabular}

${ }^{\mathrm{a}}$ Mean $\pm \mathrm{SD}$. ${ }^{\mathrm{b}}$ Significantly different from the corresponding group $(\mathrm{P}<0.05)$.

adenocarcinoma and atypical hyperplasia of the group treated with $\mathrm{E}_{2}$ and $G l$ radix were significantly lower than those of the group treated with $\mathrm{E}_{2}$ alone (6). A similar tendency was confirmed by GL treatment. Since atypical hyperplasia is considered to be a direct precursor of endometrial adenocarcinoma (29), the decreased expression of atypical hyperplasia was suggested to support the chemopreventive effects of these agents in the endometrial carcinogenesis.

It has been reported that $G l$ radix contains not only GL but also isoflavones such as liquiritin, licoricone, licoflavone and formononetin (30). Isoflavones are known to act as chemopreventive agents for carcinomas including endometrial carcinoma (16). As summarized in Fig. 4, the incidence of adenocarcinoma in the $G l$ radix plus $\mathrm{E}_{2}$ group was lower than that in the GL plus $\mathrm{E}_{2}$ group (11.8 and 19.4\%). The effectiveness for the preventive effect of Gl radix may therefore be related to the presence of other isoflavones in Gl radix.

Clinical studies have shown that the COX-2 expression is associated with the estrous cycle in the uteri (31). In the present study, the COX-2 mRNA expression significantly increased after $\mathrm{E}_{2}$ stimulation, and COX-2 mRNA was overexpressed in adenocarcinoma and atypical endometrial hyperplasia in the mouse uterus, thus suggesting the overexpression of $\mathrm{COX}-2$ to be related to $\mathrm{E}_{2}$-induced endometrial carcinogenesis in mice. It is therefore suggested that the suppression of the overexpression of COX-2 is an effective strategy for endometrital cancer prevention.
In this study, GL and $G l$ radix suppressed expression of COX-2 as well as the internal cytokines, IL- $1 \alpha$ and TNF- $\alpha$ expression in the mouse uterine corpora. Meanwhile, it is known that TNF- $\alpha$ and IL- $1 \alpha$ also play a significant role in both human and rodent carcinogenesis $(16,32)$. TNF- $\alpha$ has also been reported to stimulate tumor promotion and the progression of initiated cells and premalignant cells in mice (33). Therefore, the inhibition of TNF- $\alpha$ and IL- $1 \alpha$ mRNA expression is considered to contribute to cancer prevention $(16,32,33)$.

In summary, we report herein that $G l$ radix is an efficient preventive agent for endometrial carcinogenesis, and that GL acts as an important constituent in Gl radix, for the suppression of the carcinogenesis related to the suppression of COX-2, TNF- $\alpha$ and IL- $1 \alpha$ expression.

\section{Acknowledgements}

This study was partly supported by the research fund of Institute of Kampo Medicine (Japan).

\section{References}

1. Atherden LM: Studies with glycyrrhetic acid: inhibition of metabolism of steroids in vitro. Biochem J 69: 75-78, 1958.

2. Nishino H, Yoshioka K, Iwashima A, Takizawa H, Konishi S, Okamoto H, et al: Glycyrrhetic acid inhibits tumor-promoting activity of teleocidin and 12-O-tetradecanoylphorbol-13-acetate in two stage mouse skin carcinogenesis. Jpn J Cancer Res 77: 33-38, 1996. 
3. Agarwal R, Wang ZY and Mukhtar H: Inhibition of mouse skin tumor-initiating activity of DMBA by chronic oral feeding of glycyrrhizin in drinking water. Nutr Cancer 15: 187-193, 1991 .

4. Guyton KZ and Kensler TW: Prevention of liver cancer. Curr Oncol Rep 4: 464-470, 2002.

5. Sahar R and Sultana S: Chemopreventive activity of glycyrrhizin on lead acetate mediated hepatic oxidatives stress and its hyperproliferative activity in Wistar rats. Chem Biol Interact 160: 61-69, 2006.

6. Niwa K, Hashimoto M, Morishita S, Yokoyama Y, Mori H and Tamaya T: Preventive effects of Glycyrrhizae radix extract on estrogen-related endometrial carcinogenesis in mice. Jpn J Cancer Res 90: 726-732, 1999.

7. Lian Z, Fujimoto J, Yokoyama Y, Niwa K and Tamaya T: Herbal complex suppresses telomerase activity in chemoendocrine resistant cancer cell lines. Eur J Gynaecol Oncol 22: 347-349, 2001.

8. Niwa K, Hashimoto M, Morishita S, Lian Z, Tagami K, Mori H and Tamaya T: Preventive effects of Juzen-taiho-to on N-methyl$\mathrm{N}$-nitrosourea and estradiol-17ß-induced endometrial carcinogenesis in mice. Carcinogenesis 22: 587-591, 2001.

9. HaoX, Bishop AE, Wallace M, Wang H, Willcocks TC, Maclouf $\mathrm{J}$, et al: Early expression of cyclo-oxygenase-2 during sporadic colorectal carcinogenesis. J Pathol 187: 295-301, 1999.

10. Liu CH, Chang SH, Narko K, Trifan OC, Wu MT, Smith E, et al: Overexpression of cyclooxygenase-2 is sufficient to induce tumorigenesis in transgenic mice. J Bio Chem 276: 18563-18569, 2001.

11. Badawi AF and Badr MZ: Chemoprevention of breast cancer by targeting cyclooxygenase-2 and peroxisome proliferatoractivated receptor-gamma (Review). Int J Oncol 20: 1109-1122, 2002.

12. Fujita H, Koshita K, Keller ET, Takahashi Y, Yoshimito T, Namiki M, et al: Cyclooxygenase-2 promotes prostate cancer progression. Prostate 53: 232-240, 2002.

13. Hahm KB, Lim HY, Sohn S, Kwon HJ, Lee KM, Lee JS, et al: In vitro evidence of the role of COX-2 in attenuating gastric inflammation and promotion gastric carcinogenesis. J Environ Pathol Taxicol Oncol 21: 165-176, 2002.

14. Takahashi T, Kozaki K, Yatabe Y, Achiwa H and Hida T: Increased expression of COX-2 in the development of human lung cancers. J Environ Pathol Taxicol Oncol 1: 177-181, 2002.

15 Tong BJ, Tan J, Tajeda L, Das SK, Chapman JA, DuBois RN, et al: Heightened expression of cyclooxygenase-2 and peroxisome proliferator activated receptor-delta in human endometrial adenocarcinoma. Neoplasia 2: 483-490, 2000.

16. Lian Z, Niwa K, Tagami K, Hashimoto M, Gao J, Yokoyama Y, et al: Preventive effects of isoflavones, genistein and daidzein, on estradiol-17ß-related endometrial carcinogenesis in mice. Jpn J Cancer Res 92: 726-734, 2001.

17. Wei H, Browen R, Zhang X and Lebwohl M: Isoflavone genistein inhibits the initiation and promotion of two-stage skin carcinogenesis in mice. Carcinogenesis 19: 1509-1514, 1998.

18. Castrilli G, Tatone D, Diodoro MG, Rosini S, Piantelli M and Musiani P: Interleukin 1 alpha and interleukin 6 promote the in vitro growth of both normal and neoplastic human cervical epithelial cells. Br J Cancer 75: 855-859, 1997.
19. Suganuma M, Okabe S, Marino MW, Sakai A, Sueoka E and Fujiki H: Essential role of tumor necrosis factor alpha (TNFalpha) in tumor promotion as revealed by TNF-alpha-deficient mice. Cancer Res 59: 4516-4518, 1999

20. Chomczynski P and Sacchi N: Single-step method of RNA isolation by acid guanidinium thiocyanate-phenol-chloroform extraction. Anal Biochem 162: 156-159, 1987.

21. Jang M and Pezzuto JM: Effects of resveratrol on 12-O-tetradecanoylphorbol-13-acetate-induced oxidative events and gene expression in mouse skin. Cancer Lett 134: 81-89, 1998.

22. Lomedico PT, Gubler U, Hellmann CP, Dukovich M, Giri JG, Pan YC, et al: Cloning and expression murine interleukin-1 cDNA in Escherichia coli. Nature 312: 458-462, 1984.

23. Fransen L, Muller L, Marmenout RA, Van der Heyden J, Tavernier J, Kawashima E, et al: Molecular cloning of mouse tumor necrosis cDNA and its eukaryotic expression. Nucl Acid Res 13: 417-429, 1985.

24. Sabath D, Broome HE and Prystowsky MB: mRNA is a major interleukin 2-induced transcript in a cloned T-helper lymphocyte. Gene 91: 185-191, 1990.

25. Krajewski M, Krajewski S, Epstein JI, Shabaik A, Sauvageot J, Song K, et al: Immunohistochemical analysis of bcl-2, bax, bcl-X, and mcl-1 expression in prostate cancers. Am J Pathol 148: 1567-1576, 1996.

26 Fujiwaki R, Iida K, Kanasaki H, Ozaki T, Hata K and Miyazaki K: Cyclooxygenase-2 expression in endometrial cancer: correlation with microvessel count and expression of vascular endothelial growth factor and thymidine phosphorylase. Hum Pathol 33: 213-219, 2002.

27. Niwa K, Hashimoto M, Morishita S, Yokoyama Y, Lian Z, Tagami K, et al: Preventive effects of danazol on endometrial carcinogenesis in mice. Cancer Lett 158: 133-139, 2000.

28. Silverberg EJ: Definitions and explanatory notes, uterine corpus. In: Histological Classification of Tumors of the Female Genital Tract. Scully RE, Bonfiglio TA, Kurman RJ, Silverberg SG and Wilkinson EJ (eds). 2nd edition. WHO, Geneva, pp13-18, 1994

29. Niwa K, Morishita S, Murase T, Mudugdo A, Tanaka T, Mori H, et al: Chronological observation of mouse endometrial carcinogenesis induced by N-methyl-N-nitrosourea and 17ß-estradiol. Cancer Lett 104: 115-119, 1996.

30. Price KR and Fenwick GR: Naturally occurring estrogens in foods - a review. Food Addit Contam 2: 73-106, 1985.

31. Arosh JA, Parent J, Chapdelaine P, Sirois J and Fortier MA: Expression of cyclooxygenases 1 and 2 and prostaglandin $\mathrm{E}$ synthase in bovine endometrial tissue during the estrous cycle. Biol Reprod 67: 161-169, 2002.

32. Tanaka T, Kohno H, Murakami M, Shimada R and Kagami S Colitis-related rat colon carcinogenesis induced by 1-hydroxy anthraquinone and methylazoxymethanol acetate. Oncol Rep 7: 501-508, 2000.

33 Fujiki H, Suganuma M, Okabe S, Sueoka E, Suga K, Imai K and Nakachi K: A new concept of tumor promotion by tumor necrosis factor-alpha, and cancer preventive agents (-)-epigallocatechin gallate and green tea - a review. Cancer Detect Prev 24: $91-99,2000$ 